ТЕОРЕТИЧНЕ ОБҐРУНТУВАННЯ ТЕХНОЛОГІЇ ФОРМУВАННЯ КОМПЕТЕНТНОСТЕЙ МАЙБУТНІХ ОФІЦЕРІВ НАЦІОНАЛЬНОЇ ГВАРДІЇ УКРАЇНИ

\title{
THEORETICAL GROUND OF THE COMPETENCIES FORMATION TECHNOLOGY AMONG THE FUTURE OFFICERS OF THE NATIONAL GUARD OF UKRAINE
}

Статтю присвячено аналізу сутності технології формування компетентностей майбутніх офріцерів Національної гвардії України. Зазначено, що відповідно до стандартів НАТО навчання у вищих військових навчальних закладах повинно базуватися на засадах компетентнісного підходу, що вимагає нового технологічного забезпечення освітнього процесу у таких закладах освіти. А також відповідно до концепції розвитку сектору безпеки і оборони України, яка затверджена Указом Президента України від 14 березня 2016 р. № 92/2016, сучасний офріцер має відповідати стандартам країн - членів НАTO та володіти набором компетентностей, які забезпечать виконання профресійної діяльності на високому рівні.

Констатовано, що офріцери Національно гвардії України залучаються до протидії як внутрішнім, так і зовнішнім загрозам національній безпеці України, що вимагає від них широкого світогляду, національно-патріотичної свідомості, готовності до управлінської діяльності та взаємодії із цивільним населенням під час виконання службовобойових завдань.

Визначено основні протиріччя підготовки майбутніх офріцерів Національної гвардіі України.

Для визначення сутності та структури педагогічної технології проведено історичний аналіз наукової літератури. Розглянуто різні наукові підходи до поняття «педагогічна технологія».

Розглянуто роботи науковиів, в яких запропоновано конкретні педагогічні технологіі для вищої військової школи, метою яких $є$ вирішення завдань щодо формування певних компетентностей за результатами навчання.

Проаналізовано погляди науковців щодо етапів реалізації педагогічних технологій в освітньому процесі.

Виділено педагогічні умови реалізації технології формування компетентностей майбутніх офріцерів Національної гвардії України. Сорормульовано основні напрями вдосконалення навчально-виховного процесу щодо цілеспрямованого формування компетентностей майбутніх офріцерів Національноі гвардії України.
Ключові слова: майбутні осріцери Начіональної гвардії України, вищий військовий навчальний заклад, профресійна підготовка, педагогічна технологія, етапи педагогічної технології, службово-бойові завдання.

The article analyses the essence of the competencies forming among future officers. According to the NATO standards, higher military education should be based on the principles of competence. They require the new technological supplement of the educational process. Moreover, following the convention on the development of the security and defense sector in Ukraine (approved by the Decree of the President of Ukraine from 14 March 2016 № 92/2016), the modern officer must meet the NATO countries' standards. It means to have competencies, which allow conducting professional activity at a high level. The officers of the National Guard of Ukraine are involved in counteracting both internal and external national security threats. It requires them a broad outlook, national and patriotic consciousness, readiness for management activity, and interaction with civilians during service and combat tasks.

The article determines the main contradictions in preparing the future National Guard officers.

There is the historical analysis of scientific literature in the paperwork, which defines the essence and structure of pedagogical technology. The different scientific approaches to the concept of "pedagogical technology" are also represented. Furthermore, there are concrete pedagogical technologies for higher military schools proposed by the scholars ' papers. Their purpose is to handle the problem in forming definite competencies at the result of the study.

The scholars ' points on the stages of pedagogical technologies realization during the study process were analyzed.

The article outlines the pedagogical conditions to form competence among future officers. It also represents the main ways to improve the study and education process, focused on the competencies formation.

Key words: the future officers of the National Guard of Ukraine, higher military educational institute, professional training, pedagogical technology, the stages of pedagogical technology, service and combat tasks.

\section{Постановка проблеми в загальному} вигляді. Сучасні вимоги до професійної підготовки офріцерів військових фрормувань України, зокрема й Національної гвардії, вимагають суттєвих змін у системі вищої військової освіти. Це зумовлено не лише існуючою військово-політичною ситуацією в Україні, а й глобальними тенденціями в розвитку освітніх систем, необхідністю їх подальшого вдосконалення в контексті домі- нування компетентнісної парадигми. Зокрема, у нашій державі це знайшло своє відображення в оновленні нормативно-правової бази забезпечення освітнього процесу. Так, були ухвалені закони «Про вищу освіту» (2014р.), «Про освіту» (2017 р.) та інші підзаконні акти. Своєю чергою, це мотивувало науково-педагогічних працівників до пошуку нових технологій навчання на засадах компетентнісного підходу [1; 2]. 
Традиційні освітні технології, що переважно використовувалися у системі вищої військової освіти, значно обмежували розвиток профресійних якостей майбутніх офріцерів. Відповідно до стандартів НАТО, навчання у вищих військових навчальних закладах повинно базуватися на засадах компетентнісного підходу. А це, своєю чергою, потребує нового технологічного забезпечення освітнього процесу у таких закладах освіти. Передусім під цим ми розуміємо створення нових педагогічних технологій формування компетентностей у майбутніх ооріцерів.

Керівництво держави та НГУ сьогодні вимагає, щоб офріцери НГУ мали широкий світогляд, були готовими до управлінської діяльності, якісно реалізовували державну політику у сфері національнопатріотичного та правового виховання особового складу НГУ з метою виховання національної свідомості та самосвідомості, історичної пам'яті, відданості Українському народові, фрормування правової свідомості, поваги до законів, переконання в необхідності їх свідомого виконання як основи дисципліни та правопорядку у військах, уміли ефективно взаємодіяти із цивільним населенням під час виконання службово-бойових завдань.

Ураховуючи вимоги сьогодення, необхідно зазначити, що роль викладача ВВНЗ докорінно змінюється, він стає організатором самостійної активної пізнавальної діяльності майбутніх офіцерів, тобто компетентним консультантом.

Нова освітня парадигма має забезпечити здобувачів вищої військової освіти не лише конкретними знаннями, а й здатністю самостійно та активно діяти, приймати ефективні управлінські рішення, швидко адаптуватися до зміни умов обстановки під час виконання службово-бойових завдань. Це завдання вирішить не стільки зміст освіти, скільки інноваційні технології навчання. Отже, сьогодні активно впроваджуються нові педагогічні технології в систему військової освіти. А їх широке впровадження дасть змогу змінити саму парадигму освіти й удосконалити процес підготовки майбутніх офріцерів Національної гвардії України.

Актуальність цієї проблеми також набуває усе більшого значення через існування низки загроз національній безпеці України, як зовнішніх (збройна агресія і порушення територіальної цілісності України з боку Російської Федерації, мілітаризація нею тимчасово окупованих територій, нарощування Російською Федерацією поблизу державного кордону України угруповання військ із потужним ударно-наступальним потенціалом, пандемії різних захворювань), так і внутрішніх (спроби дестабілізації соціально-політичної та економічної ситуації з боку певних політичних сил та громадських організацій та ін.).

Отже, сьогодні перед нами гостро стоїть проблема вдосконалення професійної підготовки май- бутніх офріцерів та впровадження в освітній процес ефективних педагогічних технологій формування компетентностей майбутніх офріцерів Національної гвардії України.

Аналіз останніх досліджень і публікацій. Складний і динамічний характер сучасної службово-бойової діяльності Національної гвардії України, використання в ній новітніх інфрормаційних технологій, зразків озброєння та військової техніки, поява нових фрорм ведення бойових дій, необхідність бути готовим до виконання широкого кола завдань як у сорері безпеки, так і у сорері оборони держави зумовлюють об'єктивну потребу в удосконаленні системи професійної підготовки майбутніх офріцерів Національної гвардії України. Важливим складником цього процесу $€$ фрормування у них низки компетентностей, необхідних для якісної підготовки до подальшого виконання завдань.

У новій освітній парадигмі відбувається процес зближення освітнього процесу та професійної діяльності на засадах компетентнісного підходу. Як зазначає І. Семенова, основою попередніх освітніх стандартів були знання, тобто фрундаментальна підготовка, такі компоненти, як уміння та навички носили допоміжний характер і досить часто зводилися до вміння використовувати свої знання. При цьому вважалося, що у ВВНЗ краще знають, якими знаннями повинен володіти випускник тієї або іншої спеціальності, які знання та в якій кількості необхідно давати під час реалізації відповідної освітньої програми. Тобто навчання реалізовувалося через вектор ідеалізованого уявлення про професію, до теоретичного навчання цій профресії. У професійній діяльності теорія не завжди співпадає з практичною діяльністю, що було причиною головного недоліку молодих спеціалістів - відсутністю в них уміння застосовувати теоретичні знання для вирішення конкретних професійних завдань [3].

У цьому контексті слід навести точку зору Г. Хоружого та інших авторів, які стверджують, що завдяки новим вимогам часу переосмислення теоретичних та практичних основ педагогіки є одним із найважливіших завдань розвитку науки. Передусім йдеться про нові компетентності, що стосуються вибудови певної профресійної кар'єри. За таких умов педагогічна наука за своїм змістом і технологіями все далі відходить від класичного їі розуміння [4].

В. Новіков зазначає, що в постіндустріальному суспільстві розуміння освіти сприймається як надбання особистості, як засіб її самореалізації в житті, як засіб побудови особистої кар'єри. А це змінює цілі навчання, його мотиви, фрорми і методи [5].

Формування компетентностей у майбутніх офріцерів Національної гвардії України є складною педагогічною проблемою, яка потребує свого наукового і практичного вирішення, адже вдоскона- 
лення освітнього процесу у ВВНЗ є вимогою сьогодення і головним завданням, яке стоїть перед профресорсько-викладацьким складом ВВНЗ. Майбутні ооріцерські кадри є запорукою незалежності та суверенітету нашої держави, спокою громадян та сталого розвитку суспільства. Україна потребує висококваліфрікованих професійних військових кадрів, які зможуть діяти в нестандартних умовах.

Відповідно до Концепції розвитку сектору безпеки й оборони України, яка затверджена Указом Президента України від 14 березня 2016 р. № 92/2016, сучасний офіцер має відповідати стандартам країн - членів НАТО та володіти набором компетентностей, які забезпечать виконання професійної діяльності на високому рівні. Концептуальні положення професійної підготовки майбутніх офріцерів за навчальними програмами базуються на положеннях таких нормативно-правових актів: Конституції України, Воєнної доктрини України, затвердженої Указом Президента України від 24 вересня 2015 р. № 555, Указу Президента України «Про стратегічний оборонній бюлетень України» від 6 червня 2016 р. № 240, Стратегії національної безпеки України, затвердженої Указом Президента України від 14 вересня 2020 р. № 392, Директиви командувача НГУ «Про вдосконалення організації роботи з особовим складом у Національній гвардії України» від 26.06.2017 № 15 тощо.

Проте, незважаючи на те що процес переходу системи військової освіти України на освітні стандарти країн - членів НАТО триває, педагогічні технології фрормування окремих компетентностей майбутніх офріцерів сьогодні розкрито не зовсім повно.

Першочергового розв'язання, на нашу думку, вимагають такі суперечності, які, на нашу думку, існують сьогодні в системі підготовки майбутніх офріцерів НГУ: між вимогами до профресійної діяльності офріцерів НГУ і наявним рівнем сорормованості соціально-правової компетентності майбутніх офріцерів НГУ; між динамікою соціальних явищ у військових колективах та недосконалістю технологій підготовки курсантів до них у ВВН3; між вимогами до професійних, особистісних і індивідуально-психічних якостей, що необхідні майбутньому офіцеру НГУ, та недоліками їх формування у процесі його підготовки тощо.

Мета статті - визначити сутність та проаналізувати основні педагогічні технології у вищій, зокрема військовій, освіті, та сфрормулювати основні напрями вдосконалення навчально-виховного процесу щодо використання ефективних методик фрормування компетентностей майбутніх офріцерів Національної гвардії України.

Виклад основного матеріалу. Зазначимо, що загальні питання технологічного підходу в освіті, його концептуальні положення відображено в роботах В. Безпалька, М. Бершадського, Л. Буркової, В. Гузеєва, М. Капустіна, М. Кларіна, В. Лозової,
О. Пєхоти, Г. Селевко, С. Сисоєвої, Н. Тализіної, П. Третьякова, Н. Щуркової, Якиманської та ін.

Г. Коджаспірова та ін. визначають, що педагогічна технологія - новий (із 1950-х років) напрям у педагогічній науці, який займається конструюванням оптимальних навчальних систем, проєктуванням навчальних процесів [6, с. 905-907].

С. Бондар надає ґрунтовне визначення технології навчання. На його думку, технологія навчання -це інтегративна модель навчально-виховного процесу з чітко визначеними цілями, діагностикою поточних і кінцевих результатів, розподілом навчально-виховного процесу на окремі компоненти. Технологія навчання передбачає чітке та неухильне виконання певних навчальних дій в умовах оперативного зворотного зв'язку [6, с. 906-907].

О. Дубініна наголошує, що технологічний вплив повинен визначатися педагогічними цілями, обставинами застосування, бути організованим креативно, тому що кількість змінних, що підлягають урахуванню в момент впливу, дуже велика, a їх поєднання, взаємодія, взаємовплив - ще більше. Авторка підкреслює, що сучасна педагогічна технологія повинна мати такі якості, що одночасно є й методологічними вимогами до технологій, і критеріями технологічності, а саме: алгоритмічність, варіативність, відтворюваність, візуалізація, гнучкість, діагностичність, доцільність окремих елементів, ієрархічність, еоективність, єдність змістової та процесуальної частин, керованість, комплексність, концептуальність, логічність, наступність, науковість, наявність зрозумілих процедурних характеристик, оптимальність, послідовність, процесуальність, прогнозованість, розвиваючий характер, системність, структурованість, цілісність [8].

Г. Селевко прирівнює термін «педагогічна технологія» до поняття «освітня технологія». Він визначає його як систему фрункціонування усіх компонентів педагогічного процесу, яка побудована на науковій основі, запрограмована у часі й у просторі та веде до намічених результатів [9, с. 4].

У глосарії термінів ЮНЕСКО поняття «педагогічна технологія» трактується як конструювання та оцінювання освітніх процесів шляхом урахування людських, часових інших ресурсів для досягнення ефрективності освіти. Педагогічна технологія відповідає на питання: «Як, яким чином (методами, прийомами, засобами) досягти поставленої педагогічної мети, установлюючи порядок використання різноманітних моделей навчання?». Таким чином, технологія - це комплекс, що складається із:

- запланованих результатів;

- засобів оцінювання для корекції та вибору методів, прийомів навчання, оптимальних для кожної конкретної ситуації.

С. Бондар уважає, що структура технології навчання має концептуальну основу; змістовну 
частину (цілі навчання, зміст навчального матеріалу); процесуальну частину (організація навчального процесу, методи і форми навчальної діяльності учнів та вчителів - управління навчальним процесом, діагностика навчального процесу) [6].

Аналіз військово-наукових джерел дає змогу констатувати, що останнім часом оприлюднено низку наукових робіт, де запропоновано конкретні педагогічні технології для вищої військової школи, метою яких $є$ вирішення завдань щодо формування певних компетентностей за результатами навчання.

На думку А. Романишина, профресійна діяльність офріцерів багатофрункціональна. Вона є складною системою різних взаємопов'язаних видів військової праці. Автор наголошує, що випускники військового навчального закладу повинні вміти аналізувати й оцінювати військово-політичну, морально-психологічну та інсрормаційну обстановку та управляти військом з урахуванням цих чинників [7].

О. Міршук розробив технологію фрормування педагогічної компетентності у магістрів військовосоціального управління. М. Голова та ін. досліджували формування управлінської компетентності майбутніх ооріцерів. О. Лаврут та ін. запропонували підходи до фрормування професійних компетентностей у майбутніх ооріцерів під час вивчення дисципліни «Організація військового зв'язку». О. Чернишенко розробив технологію використання мультимедійних засобів у професійній підготовці майбутніх офріцерів внутрішніх військ.

Деякі науковці, що розглядали педагогічні технології, зробили акцент на дослідженні етапів їх реалізації в освітньому процесі.

Так, на думку М. Кларіна, більшість педагогічних технологій складається з чотирьох етапів:

- постановка цілей та їх максимальне уточнення, фрормулювання навчальних цілей з орієнтацією на досягнення результатів;

- підготовка навчальних матеріалів і організація всього процесу навчання згідно з навчальними цілями;

- оцінка поточних результатів, корекція навчання, спрямована на досягнення поставлених цілей;

- заключна оцінка результатів [10].

Із точки зору С. Бондаря, будь-яка технологія навчання має такі етапи:

1. Визначення чіткої системи цілей, що фрормуються, як правило, через результати навчання.

2. Конструювання навчального циклу.

3. Реалізація запланованих завдань.

4. Контроль, оцінка й аналіз результатів діяльності учнів.

5. Повторне відтворення циклу без змін або 3 коригуванням [6, с. 906-907].

О. Міршук уважає, що педагогічна технологія передбачає наявність таких етапів:

1. Підготовчо-діагностичного.

2. Мотиваційно-цільового.
3. Когнітивно-орієнтувального.

4. Діяльнісно-операційного.

5. Оцінно-корекційного.

Ґрунтуючись на вищевикладеному, виділимо необхідні педагогічні умови реалізації технології формування компетентностей майбутніх офріцерів НГУ: активне впровадження у навчальний процес методик та технологій, що засновані на контекстному та випереджувальному підходах до фрормування компетентностей майбутніх офріцерів НГУ; моделювання змісту майбутньої професійної діяльності офріцерів НГУ, що відображає усі аспекти проблеми сорормованості компетентностей майбутніх офріцерів НГУ.

Науковий пошук, відповідно до аналізу стану сорормованості відповідних компетентностей випускників ВВНЗ та подальших перспектив застосування технологій їх фрормування, дав змогу сформулювати основні напрями поліпшення стану справ:

- урахування досвіду провідних країн світу щодо фрормування мотиваційних установок у майбутніх офріцерів до якісного опанування навчальної програми та бажання самовдосконалюватися;

- постійний моніторинг соціально-психологічного клімату у навчальних групах та своєчасне реагування на можливі негативні прояви з метою створення атмосорери для самореалізації та самовдосконалення;

- упровадження новітніх фрорм підвищення кваліфікації викладацького складу ВВН3, у тому числі 3 отриманням практичного досвіду виконання завдань у зоні ООС;

- розроблення та застосування сучасних процедур вимірювання якості профресійної підготовки майбутніх ооріцерів;

- створення та впровадження у навчальновиховний процес сучасних комп'ютерних систем навчання курсантів, що відображають завдання, які сприятимуть фрормуванню відповідних компетентностей майбутніх офріцерів НГУ.

Висновки. У статті визначено сутність та проаналізовано основні педагогічні технології у вищій, зокрема військовій, освіті та сорормульовано основні напрями вдосконалення навчальновиховного процесу щодо цілеспрямованого фрормування компетентностей майбутніх офріцерів НГУ. У подальшому планується розроблення технології формування соціально-правової компетентності майбутніх офріцерів НГУ.

\section{БІБЛІОГРАФІЧНИЙ СПИСОК:}

1. Про вищу освіту : Закон України від 01 липня 2014 р. № 1556. URL: http://zakon2.rada.gov.ua/laws/ show/1556 (дата звернення: 30.05.2021).

2. Про освіту : Закон України від 05 вересня 2017 p. № 2145. URL: https://zakon.rada.gov.ua/laws/ show/2145 (дата звернення: 30.05.2021)

3. Яворенко Г. Педагогічні компетенції. Педагогіка. 2012. № 4. С. 45-54. 
4. Хоружий Г. Компетентнісні моделі у вищій освіті та бізнесі: зарубіжний досвід. Вісник КНТЕУ. 2018. № 1. С. 131-147.

5. Новіков В.М. Освіта як інструмент профресійної і соціальної мобільності. Людський розвиток. 2010. № 3. С. 26-35.

6. Енциклопедія освіти / за ред. В. Кремінь. Київ : Юрінком Інтер, 2008. 1040 с.

7. Романишин А. Педагогічні умови викладання навчальної дисципліни «Морально-психологічне забезпечення діяльності військовослужбовців» у ВН3. Вища школа. 2016. № 7-8(145). С. 88-96.
8. Дубініна О. Розвиток математичної культури студентів у вищих технічних навчальних закладах : монографія. Харків : Друкарня «Мадрид», 2014. 516 c.

9. Селевко Г.К. Педагогические технологии на основе активизации, интенсификации и эфрфективного управления УВП / под. ред. Г.К. Селевко. Москва : НИИ школьных технологий, 2005. 288 c.

10. Кларин М.В. Технология обучения: идеал и реальность : монография. Рига : Эксперимент, 1999. $180 \mathrm{c}$. 